\title{
Historie - en folkelig kvalitet
}

\author{
De Danske Gymnastik- og Ungdomsforeninger \\ v/konsulent Jørgen Andersen
}

En historiker blev spurgt, hvorfor det netop var det historiske, han havde valgt at arbejde med. Hvad ellers, svarede han, nuet er jo bare et kort øjeblik, og fremtiden er for fantaster.

Kan DANSK IDRAETSHISTORISK FORENING medvirke til, at danske idrætsfolk og folk $i$ det hele taget får idrætslivets hverdag placeret $i$ en historisk sammenhæng, vil det positivt kunne bidrage til at give idrætten en folkelig kvalitet.

Ikke med urette siges det om vor tids mennesker, at de er historieløse og dermed rodløse. Årsagerne hertil kan være mange, og det må være en oplagt opgave for en historisk forskning at bidrage med et materiale, der fremmer indsigt i og forståelse af de faktorer, der skjult eller åbenlyst har påvirket den udvikling, som dagen i dag er resultatet af.

Både $\mathrm{i}$ og uden for idrætskredse møder man ofte den opfattelse, at idræt er noget i sig selv, noget der uafhængigt af den omgivende virkelighed følger sine egne veje. Helt aktuelt kunne man spørge: Er det nødvendigt, som det påståes, at vi har en idrætselite, der er i stand til at klare sig internationalt? Og hvad begrundes denne nødvendighed med? Skal svaret søges inden for idrætten selv, eller er det noget uden for idrætten, der rejser krav om nødvendighed? Og hvilken nødvendighed?

I den aktuelle situation, hvor idrætten af flere grunde ser sig mere eller mindre nødsaget til at vælge retning, havde det været nyttigt med et historisk bagland for et sådant valg.

DDGU må i denne forbindelse lægge stor vægt på formidlingen af de resultater historieforskningen når frem til. Svagheden i nutidigt kulturliv, hvoraf idrætten er en væsentlig bestandel, er den omstændighed, at den nerve, som forbinder det med folkets liv, er overskåret. Historien kan medvirke til at skabe rodforbindelse, hvis historien formidles som vedkommende for andre end en lille kreds af historieinteresserede.

Her ligger en folkelig og dermed væsentlig opgave for DANSK IDRÆTSHISTORISK FORENING. 


\section{Cllegaard tog den store Pris.}

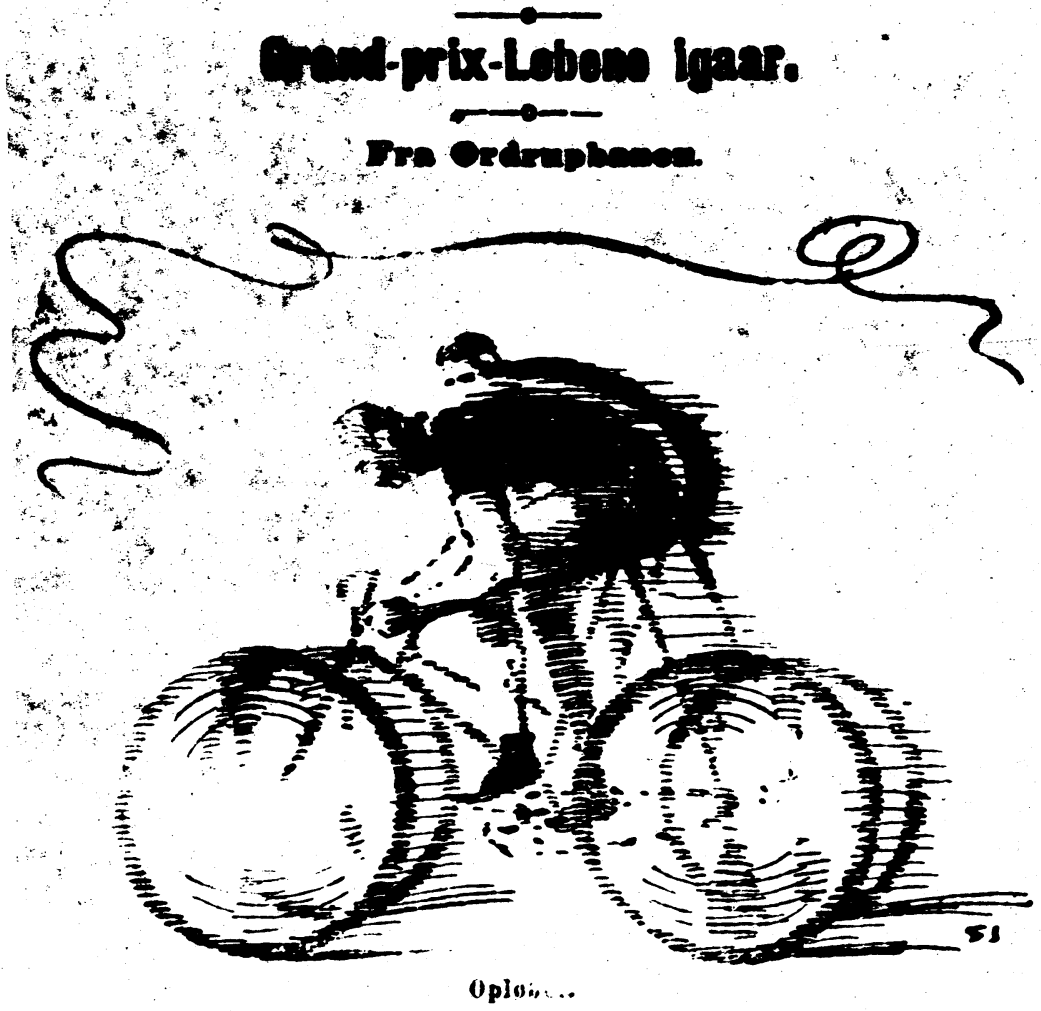

Forsidebilledet (Pol. 21.8.1905). Ordrupbanen havde regelmæssigt publikums og Politikens bevågenhed $i$ begyndelsen af dette århundrede, hvor der tit og ofte var reportager fra de mange løb. Det skyldtes ikke mindst Thorvald Ellegaard (1877-1954). Han blev professionel i 1898 og vandt Ordrupbanens Grandprix første gang i 1899 og 10 gange siden. I perioden 1901-1911 vandt han VM i sprint 6 gange. Se iøvrigt artiklen s. $137 \mathrm{ff}$. 